\title{
Trace Metal Levels in Water and Sediment from the Sakumo II and Muni Lagoons, Ghana
}

\author{
C. K. Tay*, Ruby Asmah and C. A. Biney \\ CSIR-Water Research Institute, P. O. Box AH 38, Achimota, Accra, Ghana \\ *Correspondence author; E-mail: collinstay@hotmail.com or korblatay@yahoo.co.uk
}

\begin{abstract}
Trace metal (Cu, Zn, Pb, Mn, Fe and Cd) levels were determined in water and sediment from the Sakumo II and Muni lagoons and the Mamahuma and Gbagbla Ankonu feeder streams, which feed the Sakumo II lagoon over a 1-year period, and their occurrences compared. Some physical parameters (temperature, $p \mathrm{H}$ and electrical conductivity) were also investigated. The aim of the study was to establish the pollution status of the two lagoons, as well as investigate whether the feeder streams of the Sakumo II lagoon have any influence (in terms of trace metal pollution) on the Sakumo II lagoon. Results showed that upper mean values in water and sediment were $\mathrm{Zn}(0.160 \pm 0.01 \mathrm{mg} / \mathrm{l}, 48.7 \pm 0.93 \mathrm{mg} / \mathrm{kg}), \mathrm{Pb}(0.057 \pm 0.03 \mathrm{mg} / \mathrm{l}, 29.2 \pm 3.2 \mathrm{mg} / \mathrm{kg}), \mathrm{Mn}(0.798$ $\pm 0.07 \mathrm{mg} / \mathrm{l}, 668.2 \pm 6.3 \mathrm{mg} / \mathrm{kg}), \mathrm{Cu}(0.158 \pm 0.01 \mathrm{mg} / \mathrm{l}), \mathrm{Fe}(1.32 \pm 0.73 \mathrm{mg} / \mathrm{l}, 3075 \pm 14.7 \mathrm{mg} / \mathrm{kg})$, respectively, for Sakumo II lagoon. Cd levels in water and sediment ranged from $0.004 \pm 0.001$ to $0.009 \pm 0.001 \mathrm{mg} / \mathrm{l}$ and < 0.002 to $0.88 \pm 0.05 \mathrm{mg} / \mathrm{kg}$ respectively, in the Sakumo II lagoon. Compared to the maximum contaminant level (MCL) of $0.005 \mathrm{mg} / \mathrm{l}$, the Cd levels in water from the Sakumo II lagoon may be detrimental to the 'health' of the aquatic ecosystem and, consequently, consumers of fish products from the Sakumo II lagoon. Water and sediment in the Muni lagoon had trace metal concentrations with upper mean values as $\mathrm{Cd}(<0.002 \mathrm{mg} / \mathrm{l}, 0.325$ $\pm 0.01 \mathrm{mg} / \mathrm{kg}), \mathrm{Pb}(0.033 \pm 0.01 \mathrm{mg} / \mathrm{l}, 1.46 \pm 0.18 \mathrm{mg} / \mathrm{kg}), \mathrm{Mn}(0.434 \pm 0.02 \mathrm{mg} / \mathrm{l}, 63.8 \pm 1.50 \mathrm{mg} / \mathrm{kg}), \mathrm{Zn}(0.077$ $\pm 0.001 \mathrm{mg} / \mathrm{l}, 13.7 \pm 0.18 \mathrm{mg} / \mathrm{kg}), \mathrm{Cu}(0.013 \pm 0.001 \mathrm{mg} / \mathrm{l})$ and $\mathrm{Fe}(1.085 \pm 0.26 \mathrm{mg} / \mathrm{l}, 3198.4 \pm 3.51 \mathrm{mg} / \mathrm{kg})$, respectively. Generally, trace metal levels detected in sediment from the Mamahuma ( $\mathrm{Zn}: 10.4 \pm 4.10 \mathrm{mg} / \mathrm{kg}$, $\mathrm{Pb}: 10.6 \pm 1.84 \mathrm{mg} / \mathrm{kg}, \mathrm{Mn}: 63.7 \pm 4.5 \mathrm{mg} / \mathrm{kg}, \mathrm{Fe}: 7487 \pm 23.5 \mathrm{mg} / \mathrm{kg}, \mathrm{Cd}:<0.002)$, and from the Gbagbla Ankonu ( Zn: $155 \pm 13.9$ mg/kg, Pb: $37.4 \pm 3.07$ mg/kg, Mn: $298.2 \pm 2.5 \mathrm{mg} / \mathrm{kg}$, Fe: $3209 \pm 50.5$ mg/kg, Cd: 0.70 $\pm 0.05 \mathrm{mg} / \mathrm{kg}$ ) feeder streams were relatively higher than those in the Sakumo II lagoon. Sediment from the feeder streams, therefore, provided a deeper insight into the long- term pollution state of the feeder streams and, consequently, the Sakumo II lagoon. The streams could, thus, be described as potential sources of trace metal pollution to the Sakumo II lagoon. Trace metal levels were also found to be more concentrated in sediment from the mid-section of the Muni lagoon than those from the northern and southern sections, while the northern section had more trace metal concentrations in water than those from the mid- and southern sections. The study also showed that trace metal levels detected in both water and sediment from the Sakumo II lagoon were higher relative to those from the Muni lagoon. The Sakumo II lagoon could be described as relatively more polluted with trace metal load.
\end{abstract}

\section{Introduction}

The presence of toxic metals such as lead $(\mathrm{Pb})$ and cadmium $(\mathrm{Cd})$ in environmental matrices is one of the major concerns of pollution control and environmental agencies in most parts of the world. This is mainly due to the health implications of these toxic metals since they are non-essential metals of no benefit to humans (Borgman, 1983). Their presence in aquatic ecosystems, mainly due to anthropogenic influences has far-reaching implications directly to the biota and indirectly to man. Trace metals have been referred to as common pollutants, which are widely distributed in the environment with sources mainly from the weathering of 
minerals and soils (Merian, 1991). However, the level of these metals in the environment has increased tremendously during the past decades as a result of human inputs and activities (Prater, 1975; Merian, 1991).

The Sakumo II and Muni lagoon Ramsar sites are both havens for migratory birds. They are, however, located in two distinct areas. The Sakumo II lagoon is located in an urban area and receives large volumes of untreated waste discharges from domestic, agricultural and industrial activities. The Muni lagoon, on the other hand, is located in a rural area (a relatively less populated area) and, therefore, receives less waste discharges. Fish farming is a dominant economic activity in both catchments. Obviously, the chemical status of the waters and sediments in these lagoons would have their influence on aquatic species, which might possibly reflect on the fish products.

The $p \mathrm{H}$ of a water body influences the concentration of many metals by altering their availability and toxicity. Metals such as zinc $(\mathrm{Zn})$ and cadmium $(\mathrm{Cd})$ are most likely to have increased detrimental environmental effects as a result of lowered $p \mathrm{H}$ (DWAF, 1996b). Temperatures at which environmental samples are collected and at which physico-chemical measurements are made are important for data correlation and interpretation. For instance, for domestic use, high temperatures may increase the toxicity of many substances such as trace metals in water. In addition to microbial activities within an aquatic medium, temperature and $p \mathrm{H}$ are two important factors that govern the methylation of elements such as lead $(\mathrm{Pb})$ and mercury (Hg) (Van Loon, 1982). Electrical conductivity (EC) is a useful indicator of mineralization in a water body which correlates with the total dissolved solids (TDS) in the water body.

Trace metals have been determined in potable water (Garcia et al., 1999) and fresh and marine waters (Hall et al., 2002). Although water is commonly employed as a pollution indicator by trace metals, sediment can also provide a deeper insight into the long-term pollution state of the water body. Sediment has been described as a ready sink or reservoir of pollutants including trace metals, where they concentrate according to the level of pollution (Onyari et al., 2003). The need to assess the state and quality of water and sediment from the Sakumo II and Muni lagoons, as well as the Mamahuma and Gbagbla Ankonu streams that feed the Sakumo II lagoon, in terms of their trace metal loads, becomes imperative due to the health implications that cut across the food strata, since these lagoons serve as sources of fish not only to people living in both catchments but also commercially available to the larger community.

Previous studies on pollution of coastal lagoons in Ghana covered physico-chemical characteristics (Biney, 1986), limnology (Biney, 1995) and monitoring the pollution status of coastal lagoons (Biney et al., 1998). These studies, however, did not cover all trace metals with detrimental effects on human health.

The paper seeks to identify and characterize the levels of trace metals $(\mathrm{Fe}$, $\mathrm{Cu}, \mathrm{Mn}, \mathrm{Pb}, \mathrm{Cd}$ and $\mathrm{Zn}$ ) in water and sediment from the Muni and Sakumo II lagoons, as well as the Mamahuma and Gbagbla Ankonu feeder streams which feed the Sakumo II lagoon, in order to establish the trace metal loads and, subsequently, 
determine whether the Mamahuma and Gbagbla Ankonu feeder streams are potential sources of trace metal pollution to the Sakumo II lagoon.

\section{Study areas \\ Materials and methods}

The Sakumo II lagoon occupies an area of $3.5 \mathrm{~km}^{2}$ and lies between latitude $5^{\circ} 36^{\mathrm{I}} \mathrm{N}$ and $5^{\circ} 41^{\mathrm{I}} \mathrm{N}$ and longitude $0^{\circ} 01^{\mathrm{I}} \mathrm{W}$ and $0^{\circ}$ $04^{\mathrm{I}} \mathrm{W}$, about $3 \mathrm{~km}$ west of Tema (Fig. 1). The lagoon was a typical closed lagoon (Kwei, 1974) until pipes were laid under the sand bar to enable the construction of the Accra-Tema (Beach) road. The lagoon is now permanently kept open to the sea by two parallel culverts each $70 \mathrm{~m}$ long and 1.4 $\mathrm{m}$ in diameter; thus, representing a transitory stage between a closed and an open lagoon.

There are two rainy seasons, a major season which starts in March and peaks in mid-July and a minor season which begins in mid-August and ends in October. The mean annual rainfall is about $753 \mathrm{~mm}$. Relative humidity varies an average of $65 \%$ in mid afternoon to $95 \%$ at night. Mean monthly temperatures range from a minimum of $24.7^{\circ} \mathrm{C}$ in August to a maximum of $28.1{ }^{\circ} \mathrm{C}$ in March. The lagoon and its surrounding wetlands have been designated as one of the five Ramsar sites in Ghana, where important migratory birds may be found. Seventy species of water birds have been recorded at the site with estimated maximum numbers of some 30,000 birds (Birdlife International, 2003).

Two main streams, the Mamahuma and the Gbagbla Ankonu, feed the lagoon. Both streams have been dammed to provide water for crop and livestock farming but have become polluted due to industrial and domestic activities. The sampling point on the Mamahuma feeder stream (FDS1) is about $10 \mathrm{~m}$ away from the AshaimanNungua main road, and the portion around the sampling point was used by some commercial drivers as a washing bay during the entire sampling period. The land area (about $10 \mathrm{~m}^{2}$ ) away from this sampling point houses a refuse dump, while the sampling point on the Gbagbla Ankonu feeder stream (FDS 2) is about $15 \mathrm{~m}$ away from the AccraTema Motorway. It was observed during the entire sampling period that the sampling point (FDS2) and its surrounding areas had become chocked with refuse and the entire stream became almost stagnant. The Sakumo II lagoon and the feeder streams are downstream of the major industries (e.g. Coca Cola Bottling, Printex and Kasapreko Company Ltd) in the catchments as well as residential areas.

The Muni lagoon covers an area of 4.5 $\mathrm{km}^{2}$, located $1 \mathrm{~km}$ west of Winneba and 67 $\mathrm{km}$ from Accra, and lies between latitude $5^{\circ}$ $19^{\mathrm{I}} \mathrm{N}$ and $5^{\circ} 21^{\mathrm{I}} \mathrm{N}$ and longitude $0^{\circ} 38^{\mathrm{I}} \mathrm{W}$ and $0^{\circ} 40^{\mathrm{I}} \mathrm{W}$ (Fig. 2). The lagoon is shallow, of average depth $0.6 \mathrm{~m}$, and closed to the sea for most parts of the sampling period. It is fed by two rivers, Muni and Pratu. The lagoon adjoins the Yenku Forest Reserve, which, together with the adjacent forest, form the traditional hunting grounds for the people of the area. Marine and lagoon fishing, livestock rearing, residential facilities, forest reserve, fuel wood harvesting, farming and hunting are the major land-use activities along the Muni lagoon (Biney et al., 1995). Salt winning activity was on-going at the northern section of the lagoon (Fig. 2).

\section{Samples and sampling stations}

Sampling stations for water and sediments from the Sakumo II and Muni 


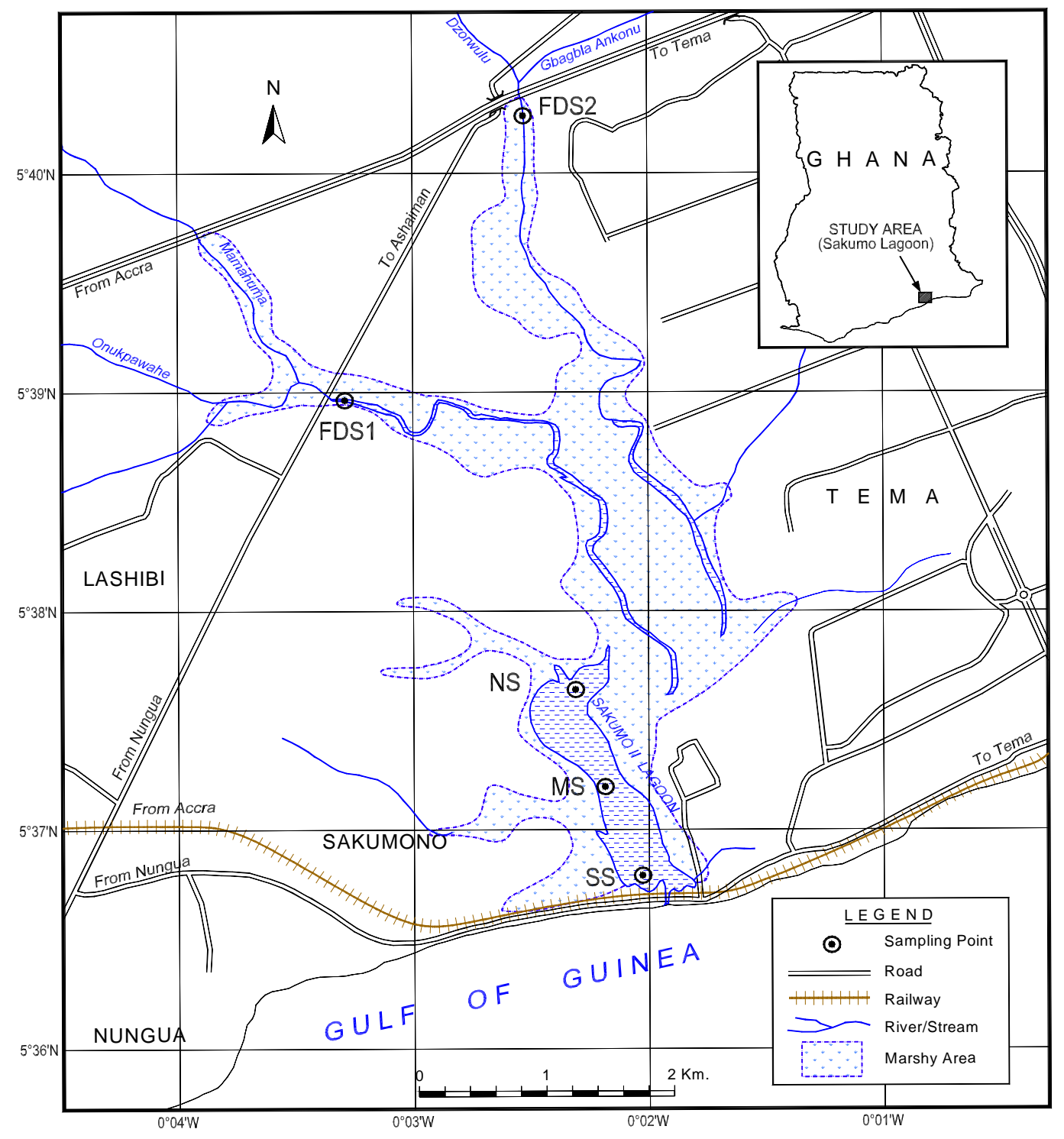

Fig. 1. Map showing the Sakumo II Lagoon, the Feeder Streams and the sampling points 


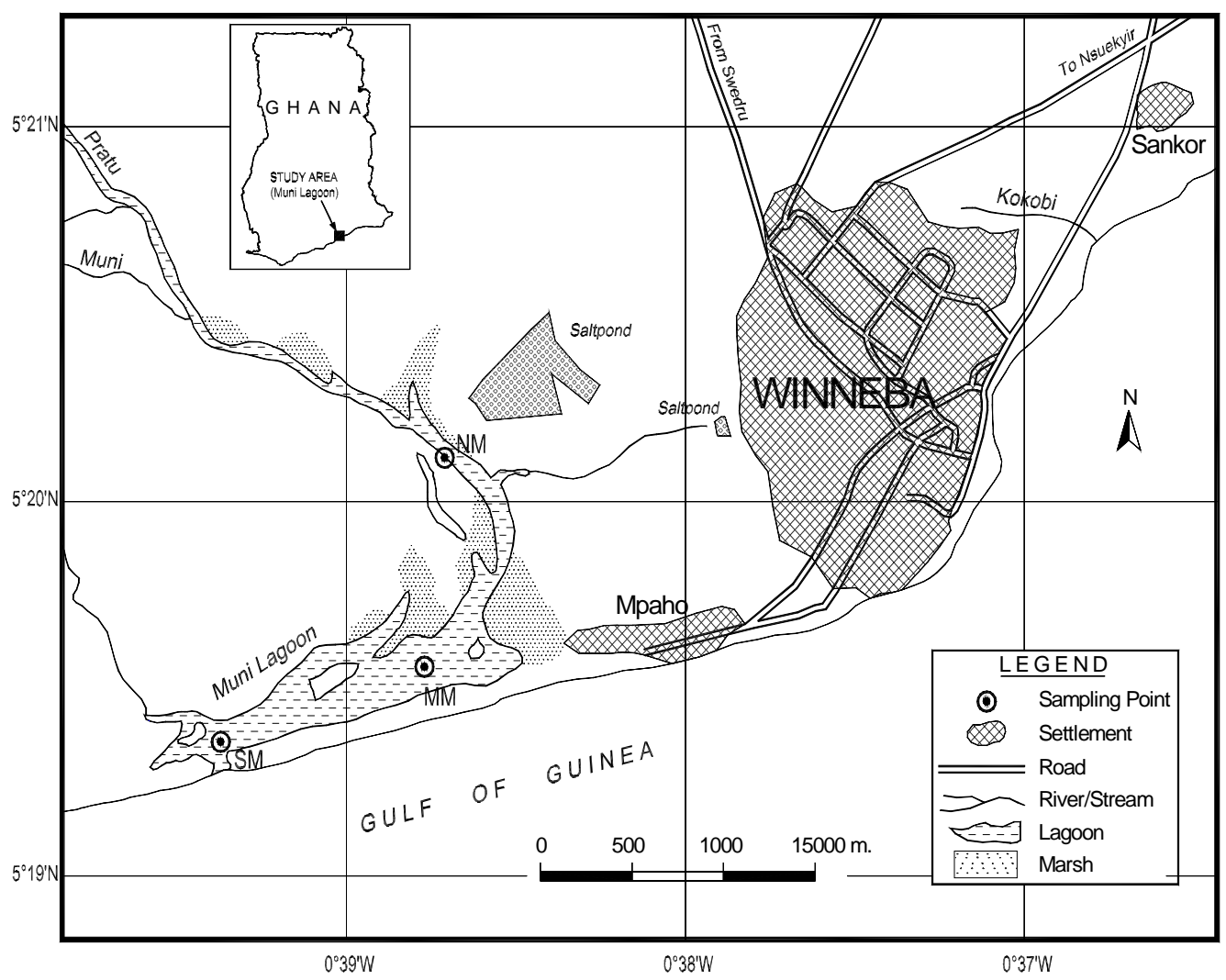

Fig. 2. Map showing the Muni lagoon and the sampling points

lagoons are presented in Fig. 1 and 2, respectively. Water and sediment samples were collected from the lagoons between November 2003 and October 2004. Five sites were selected from the Sakumo II lagoon; three from parts of the lagoon marked SS, MS and NS (Fig. 1) referred to as South-Sakumo, Mid-Sakumo and NorthSakumo, respectively, one from the Onukpawahe stream, a tributary of the Mamahuma, and one from Gbagbla Ankonu marked FDS 1 and FDS 2 (Fig. 1), referred to as feeder stream 1 and feeder stream 2 , respectively. Three sites were selected from the Muni lagoon, marked SM, MM and NM referred to as South-Muni, Mid-Muni and North-Muni respectively (Fig. 2). The sampling stations on the lagoons and the feeder streams were selected on the basis of the different activities in the catchments, which are likely to affect the quality of the lagoon waters.

Sample containers were thoroughly washed with detergent, rinsed with water followed by distilled water before soaking in $5 \% \mathrm{HNO}_{3}$ for about $24 \mathrm{~h}$. Sampling protocols, described by Claasen (1982) and Barcelona et al. (1985), were strictly adhered to during sample collection. Samples were collected in 4-litre acid- 
washed polypropylene containers below (10 $\mathrm{cm})$ the surface of the lagoon. Water samples were kept on ice in an ice-chest and transported to the Council for Scientific and Industrial Research-Water Research Institute (CSIR-WRI) laboratory and stored at $<4{ }^{\circ} \mathrm{C}$ until analyzed (normally within 1 week). Water samples for dissolved metal determination were filtered through $0.45 \mu \mathrm{m}$ pore size on acetate cellulose filters and acidified to $1 \%$ acid with $65 \%$ analytical grade $\mathrm{HNO}_{3}$. Sediment samples were collected with an Eckman grab sampler, kept frozen at $-19^{\circ} \mathrm{C}$ in polyethylene bags until analyzed (normally within 1 week). The sediment samples were put on watch glasses and placed in an oven at $60^{\circ} \mathrm{C}$ until dry. The dried sediments were homogenized and passed through a sieve of pore size $0.5 \mathrm{~mm}$.

Dry sediment of grain size $<0.5 \mathrm{~mm}$ was weighed $(0.2 \mathrm{~g})$ into a $60 \mathrm{ml}$ Teflon vessel and digested under pressure with $2 \mathrm{ml}$ concentrated nitric acid $\left(\mathrm{HNO}_{3}\right)$ by slow heating to $110^{\circ} \mathrm{C}$ for $1 \mathrm{~h}$, followed by rapid heating to $150^{\circ} \mathrm{C}$ for $7 \mathrm{~h}$. The samples were then allowed to cool to room temperature. Digested samples were transferred into polypropylene graduated tubes and made up to $25 \mathrm{ml}$ with double-distilled water for analysis (Canadian National Laboratory for Environmental Testing, 1994). Treatment and analysis of samples took place within 1 week of collection. Trace metal concentrations in water and sediment were determined by flame atomization (UNEP, 1984b) using UNICAM 969 flame atomic absorption spectrometer.

\section{Physical parameters}

$p \mathrm{H}$, temperature and electrical conductivity of the water samples were measured in situ using WTW-Multiline P4 universal meter before preserving with $5 \mathrm{ml}$ concentrated $\mathrm{HNO}_{3}$.

\section{Statistical analysis}

Analysis of variance (ANOVA) was used to compare means of trace metal concentrations in water and sediment from the lagoons and feeder streams. Comparisons of trace metal concentrations in water and sediment were done between the Sakumo II lagoon and the feeder streams, and Sakumo II and Muni lagoons to determine whether the differences in trace metal concentrations were significant or otherwise.

\section{Results and discussion}

The mean values of trace metals in water $(\mathrm{mg} / \mathrm{l} \pm \mathrm{SD})$ from Sakumo II lagoon and some physical parameters, and mean values of sediment $(\mathrm{mg} / \mathrm{kg} \pm \mathrm{SD})$ from Sakumo II lagoon are presented in Tables 1 and 2, respectively, whilst the mean values of trace metals in water $(\mathrm{mg} / \mathrm{l} \pm \mathrm{SD})$ from Muni lagoon, and some physical parameters and mean values of trace metals in sediment $(\mathrm{mg} / \mathrm{kg} \pm \mathrm{SD})$ from Muni lagoon are presented in Tables 3 and 4, respectively. Tables 5 and 6 present the statistical comparison between the mean concentrations of trace metals in water and sediment for Sakumo II and Muni lagoons, and the feeder streams.

The detection limits for trace metals using flame photometry atomic absorption spectrophotometer (FAAS) were $\mathrm{Fe}, 0.01$; $\mathrm{Mn}, 0.005 ; \mathrm{Pb}, 0.005 ; \mathrm{Cd}, 0.002 ; \mathrm{Cu}, 0.002$ and $\mathrm{Zn}, 0.005$ for water and $\mathrm{Fe}, 2.8 \mu \mathrm{g} / \mathrm{g}$ ); Mn, $33.5 \mu \mathrm{g} / \mathrm{g} ; \mathrm{Pb}, 0.55 \mu \mathrm{g} / \mathrm{g} ; \mathrm{Cd}, 0.25 \mu \mathrm{g} / \mathrm{g}$ and $\mathrm{Zn}, 4.5 \mu \mathrm{g} / \mathrm{g}$; for sediment. Limits of detection of the analyzed metals were determined as three times the standard 


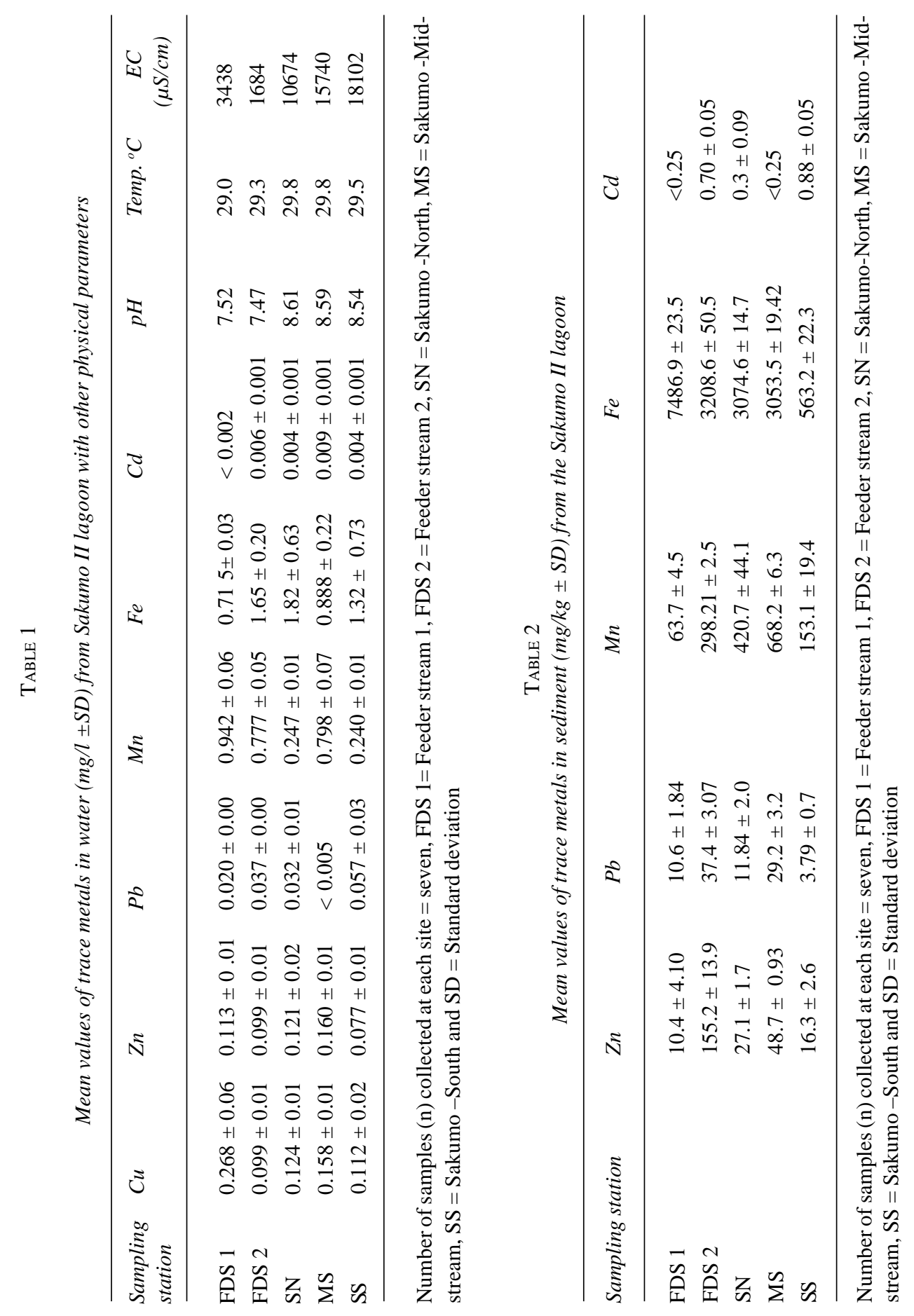

West African Journal of Applied Ecology, vol. 16, 2009 


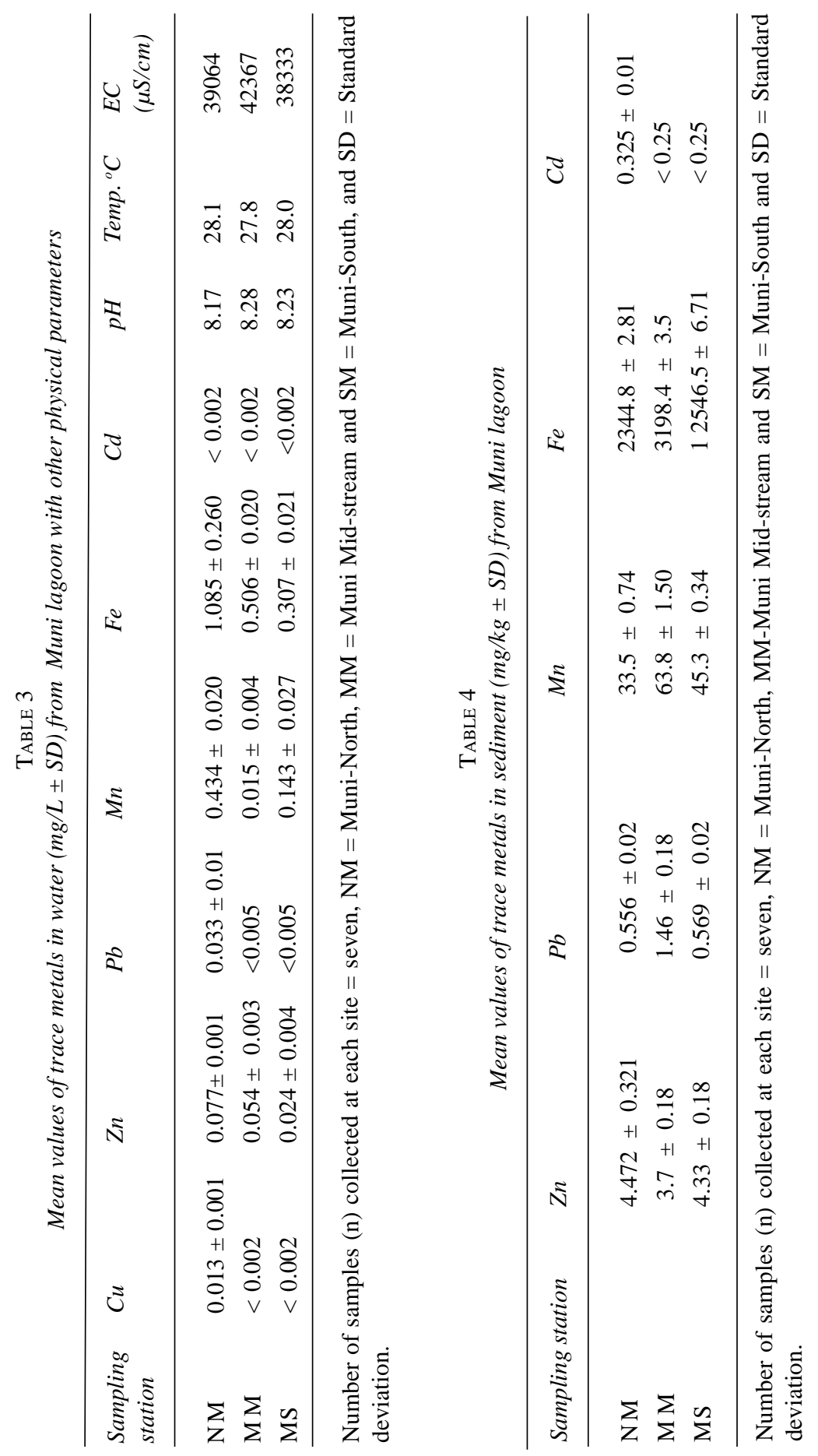


TABLE 5

Comparison between the mean concentrations of trace metals in water ( $\mathrm{mg} / \mathrm{l})$ for Sakumo II and Muni lagoons and the feeder streams.

\begin{tabular}{llllllll}
\hline \multicolumn{2}{l}{$\begin{array}{l}\text { Comparison of lagoons and } \\
\text { feeder streams }\end{array}$} & $\mathrm{Cu}$ & $\mathrm{Zn}$ & $\mathrm{Pb}$ & $\mathrm{Mn}$ & $\mathrm{Fe}$ & $\mathrm{Cd}$ \\
\hline FDS1 & Sakumo II & $\mathrm{ns}$ & $\mathrm{ns}$ & $\mathrm{ns}$ & $\mathrm{P}<0.01$ & $\mathrm{~ns}$ & $\mathrm{P}<0.05$ \\
FDS2 & Sakumo II & $\mathrm{ns}$ & $\mathrm{ns}$ & $\mathrm{P}<0.001^{*}$ & $\mathrm{~ns}$ & $\mathrm{~ns}$ & $\mathrm{~ns}$ \\
Sakumo II & Muni & $\mathrm{ns}$ & $\mathrm{ns}$ & $\mathrm{ns}$ & $\mathrm{Pf}<\mathrm{f0.01}$ & $\mathrm{ns}$ & $\mathrm{P}<0.001^{*}$ \\
\hline
\end{tabular}

ns $=$ not significant $(P<0.001), *$ highly significant

TABLE 6

Comparison between the mean concentrations of trace metals in sediment ( $\mathrm{mg} / \mathrm{kg}$ ) for Sakumo II and Muni lagoons and the feeder streams

\begin{tabular}{lllllll}
\hline $\begin{array}{l}\text { Comparison of lagoons and } \\
\text { feeder streams }\end{array}$ & $\mathrm{Zn}$ & $\mathrm{Pb}$ & $\mathrm{Mn}$ & $\mathrm{Fe}$ & $\mathrm{Cd}$ \\
\hline FDS1 & Sakumo II & $\mathrm{ns}$ & $\mathrm{ns}$ & $\mathrm{P}<0.05^{*}$ & $\mathrm{~ns}$ & $\mathrm{~ns}$ \\
FDS2 & Sakumo II & $\mathrm{P}<0.001^{*}$ & $\mathrm{P}<0.001$ & $\mathrm{~ns}$ & $\mathrm{~ns}$ & $\mathrm{~ns}$ \\
Sakumo II & Muni & $\mathrm{P}<0.001^{*}$ & $\mathrm{~ns}$ & $\mathrm{P}<0.01$ & $\mathrm{~ns}$ & $\mathrm{~ns}$ \\
\hline
\end{tabular}

ns $=$ not significant $(P<0.001), *=$ highly significant

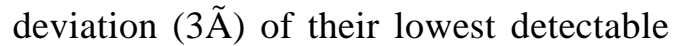
concentrations by FAAS from the mean of six replicate analyses. Good linearity was obtained from the calibration curves prepared from $1000 \mathrm{mg} / \mathrm{l}$ of each metal standard from BDH laboratory, England.

\section{Physical parameters}

Mean water $p \mathrm{H}$ of Sakumo II lagoon ranged from 7.47 to 8.61 (Tables 1 and 2), while those from the Muni lagoon ranged from 8.17 to 8.28 (Tables 2 and 3). This is an indication that, while the Sakumo II lagoon is neutral to basic in character, the Muni lagoon is basic in character. The mean conductivity values varied from 1684 to $18102 \mu \mathrm{S} / \mathrm{cm}$ and 38333 to $42367 \mu \mathrm{S} / \mathrm{cm}$ for
Sakumo II and Muni lagoons, respectively. This is a reflection of the higher salinity of the waters of the Muni lagoon than the Sakumo II lagoon. The mean water temperatures varied from 29.0 to $29.8{ }^{\circ} \mathrm{C}$ and 27.8 to $28.1{ }^{\circ} \mathrm{C}$ for Sakumo II and Muni lagoons, respectively. This is typical of shallow coastal waters in Ghana, where ambient temperatures remain within a narrow range of $25-35^{\circ} \mathrm{C}$ (Biney, 1990).

Cadmium. Cadmium $(\mathrm{Cd})$ is one of the most toxic elements with widespread carcinogenic effects in humans (Goering $e t$ al., 1994) and is widely distributed in the aquatic environment. The mean $\mathrm{Cd}$ concentrations in water from Sakumo II lagoon varied from $0.004 \pm 0.000$ to $0.009 \pm$ 
$0.001 \mathrm{mg} / \mathrm{l}$, and was highest at the mid-section and lowest (similar concentration) at both the northern and southern sections (Fig. 3). The high $\mathrm{Cd}$ value recorded at the midsection of the Sakumo II lagoon could be due to industrial and domestic effluents and urban storm-water runoff containing $\mathrm{Cd}$ laden materials. Mean Cd concentrations in water from feeder streams 1 and 2 varied from $<0.002$ to $0.006 \pm 0.001 \mathrm{mg} / \mathrm{l}$, with feeder stream 2 recording the highest $\mathrm{Cd}$ level (Fig. 3), suggestive of the relatively higher weathering of minerals and soils, discharge of domestic effluents and urban storm-water runoff containing Cd-laden materials in feeder stream 2. In the waters of Muni lagoon, mean $\mathrm{Cd}$ concentrations were all below detection limit ( Fig. 4, Table 3 ), indicative of the absence of industrialization and urbanization, which are associated with the discharge of industrial and domestic effluents and urban storm-water runoff containing Cd-laden materials.

The mean Cd concentrations in sediment from Sakumo II lagoon varied from $<0.002$ to $0.88 \pm 0.05 \mathrm{mg} / \mathrm{kg}$, highest at the southern section and lowest at the mid-section (Fig. 5). Results from the study conforms to earlier findings that sediments can be described as a ready sink or reservoir of pollutants including trace metals where they accumulate according to the level of pollution (Onyari et al., 2003), since Cd concentration in sediment from the southern section of the Sakumo II lagoon was three times that from the northern section, even though the southern section recorded the least $\mathrm{Cd}$ concentration in the waters of the Sakumo II lagoon (Fig. 3). In the case of the feeder streams 1 and 2, mean $\mathrm{Cd}$ concentrations in sediment varied from $<0.002$ to $0.70 \pm 0.05$ $\mathrm{mg} / \mathrm{kg}$, with feeder stream 2 recording the highest $\mathrm{Cd}$ value (Fig. 5). This could be due to weathering of minerals and soils, discharge of industrial and domestic effluents and urban storm-water runoff containing Cd-laden materials in feeder stream 2.

In sediments from Muni lagoon, mean $\mathrm{Cd}$ concentrations varied from $<0.002$ to 0.325

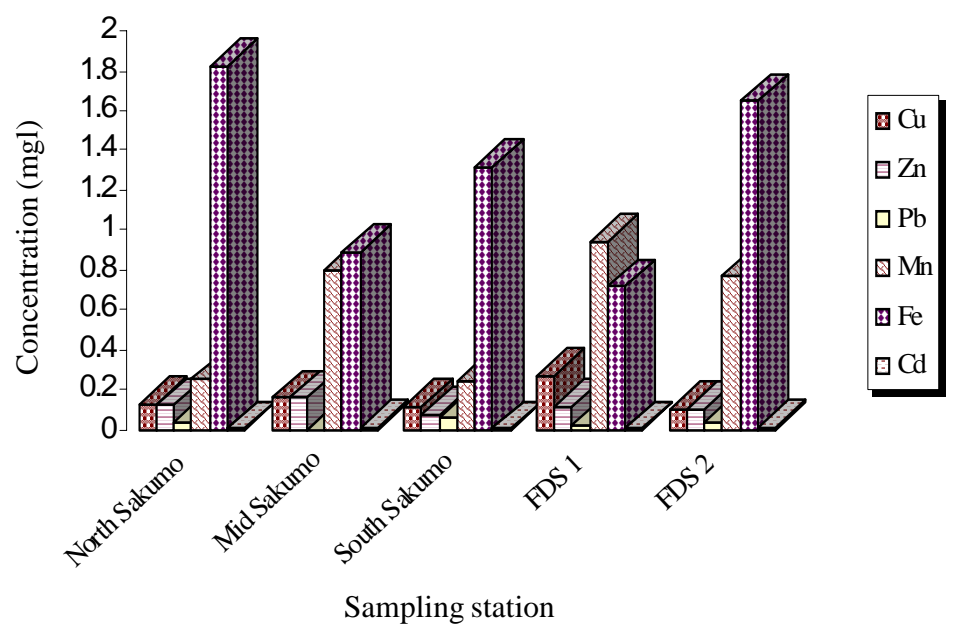

Fig. 3. Mean values of trace metals in water from Sakumo II lagoon and the feeder streams 


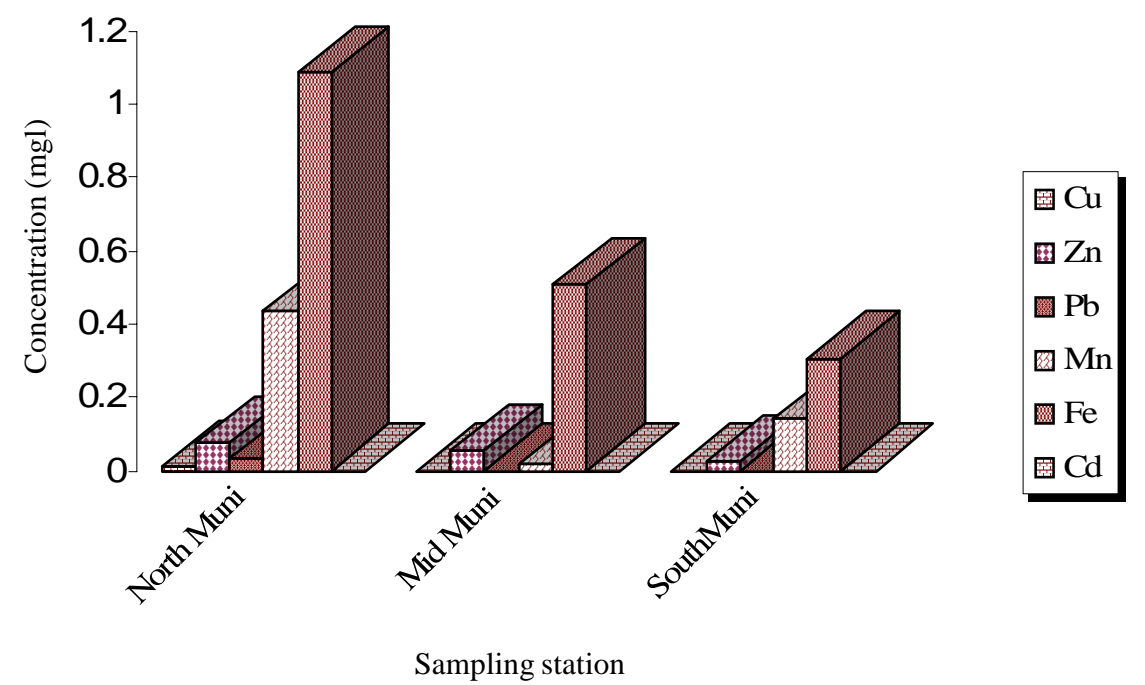

Fig. 4. Mean values of trace metals in water from the Muni lagooon

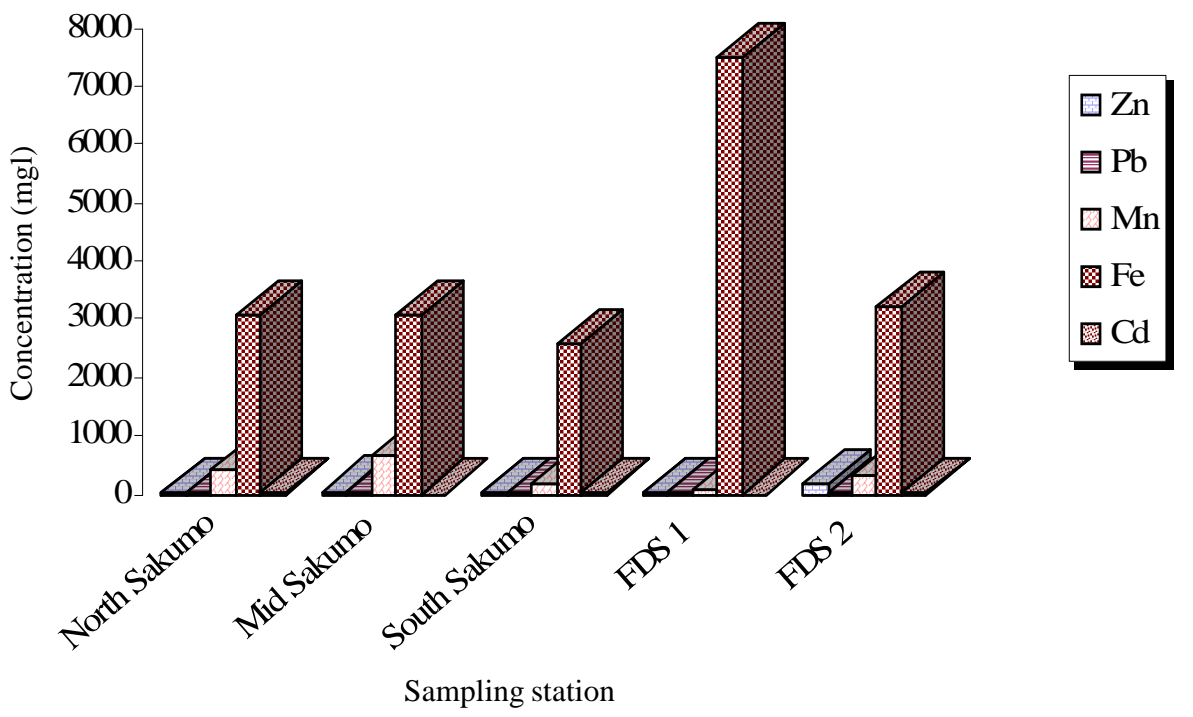

Fig. 5. Mean values of trace metals in sediment from Sakumo II lagoon and the feeder streams 
$\pm 0.01 \mathrm{mg} / \mathrm{kg}$, with the northern section recording the highest $\mathrm{Cd}$ value (Fig. 6). The high $\mathrm{Cd}$ value in this section of the Muni lagoon could be attributed to the result of weathering of minerals and soils due to the salt winning activity in the vicinity. The differences in $\mathrm{Cd}$ detected in water from FDS1 and Sakumo II lagoon was significantly high $(\mathrm{P}<0.05)$, whilst the difference in $\mathrm{Cd}$ values for FDS2 and Sakumo II lagoon was not significant (Table 5). This suggests that the Sakumo II lagoon could be serving as a ready sink for $\mathrm{Cd}$ pollution. Cd levels detected in both water (significantly higher at $P<0.001$ ) and sediment (difference not significant) from the Sakumo II lagoon were relatively higher than those detected in the Muni lagoon. This may be due to the contribution from industrial and domestic waste water runoffs and urban storm-water runoff. The mean $\mathrm{Cd}$ level detected in water from the middle-section of Sakumo II lagoon $(0.009 \pm 0.001 \mathrm{mg} / \mathrm{l})$ and feeder stream 2 $(0.006 \pm 0.001 \mathrm{mg} / \mathrm{l})$ were higher than the maximum contaminant level (MCL) of 0.005 mg/l (USEPA, 1986a) above which there may be detrimental effects to the 'health' of the aquatic ecosystem and, consequently, consumers of fish products from the Sakumo II lagoon.

Possible Cd effects in human include accumulation mainly in the kidney and liver. High concentrations have been found to lead to chronic kidney dysfunction, inducing cell injury and death by interfering with calcium (Ca) regulation in biological systems, toxicity to fish and other aquatic organisms (Woodworth \& Pascoe, 1982), and its involvement in endocrine disrupting activities, which could pose serious health problems. However, concentrations of cadmium in water are only likely to be of health concern in environments where $p \mathrm{H}$ is less than 4.5 (WHO, 2004).

The mean $\mathrm{Cd}$ levels detected in sediment from feeder stream $2,(0.70 \mathrm{mg} / \mathrm{kg})$, the northern $(0.3 \mathrm{mg} / \mathrm{kg})$ and southern $(0.88 \mathrm{mg} /$ $\mathrm{kg}$ ) sections of the Sakumo II lagoon (Table

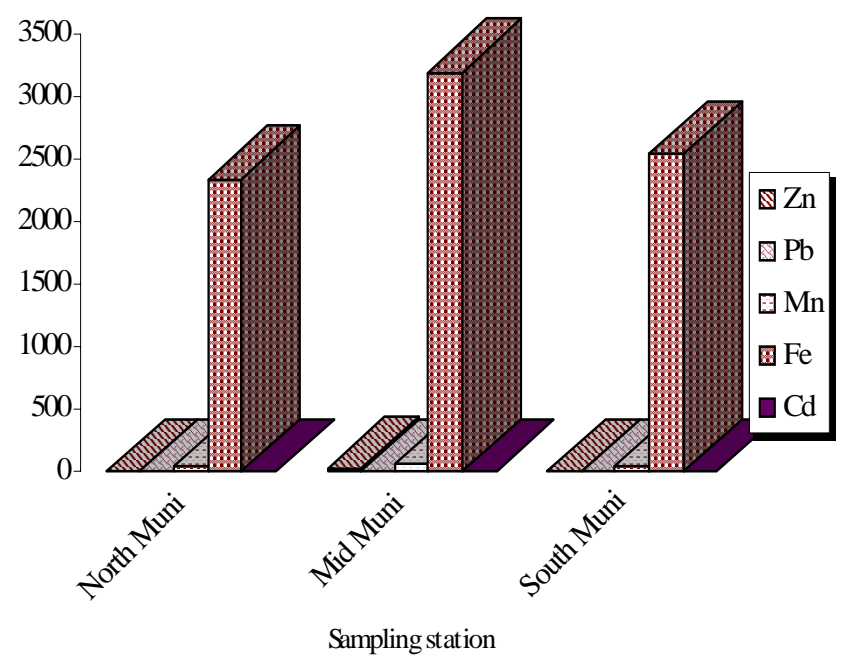

6. Mean values of trace metals in sediment from the Muni lagoon 
2) and from the northern section $(0.225 \mathrm{mg} /$ $\mathrm{kg}$ ) of the Muni lagoon (Table 4) were higher than the guideline value $(0.11 \mathrm{mg} / \mathrm{kg})$ of unpolluted marine sediments (GESAMP, 1982; Salomons \& Froster, 1984; IAEA, 1989).

Zinc. $\mathrm{Zn}$ is one of the earliest known trace metal and a common environmental pollutant, which is widely distributed in the aquatic environment. It has been found to have low toxicity effect in man. However, prolonged consumption of large doses can result in some health complications such as fatigue, dizziness and neutropenia (Hess \& Schmidt, 2002). Studies have also shown that $\mathrm{Zn}$ could be toxic to some aquatic organisms such as fish (Alabaster \& Lloyd, 1980). In the waters of the Sakumo II lagoon, mean $\mathrm{Zn}$ concentrations varied from $0.077 \pm 0.007$ to $0.160 \pm 0.01 \mathrm{mg} / \mathrm{l}$, with the mid-section recording the highest $\mathrm{Zn}$ value (Fig. 3). This could be attributed to natural sources, resulting from the weathering of minerals and soils (Merian, 1991) and atmospheric deposition from refineries. In feeder streams 1 and 2 , mean $\mathrm{Zn}$ concentrations varied from $0.099 \pm 0.011$ to $0.113 \pm 0.013 \mathrm{mg} / \mathrm{l}$, with feeder stream 1 recording the highest $\mathrm{Zn}$ value (Fig. 3). The relatively high $\mathrm{Zn}$ level in feeder stream 1 is suggestive of the influence of refuse dump and domestic sewage sources. It could also be attributed to industrial effluents (Asami, 1974).

Results also showed that the waters of Sakumo II lagoon recorded higher $\mathrm{Zn}$ values than the feeder streams (differences not significant) (Table 5). The Sakumo II lagoon may be acting as a ready sink which is receiving metal loads including $\mathrm{Zn}$ from the feeder streams. The waters of the Muni lagoon recorded mean $\mathrm{Zn}$ concentrations varying from $0.024 \pm 0.004$ to $0.077 \pm 0.010$ $\mathrm{mg} / \mathrm{l}$, with the northern section recording the highest $\mathrm{Zn}$ value (Fig. 4), This could be attributed to the weathering of minerals and soils as a result of the salt winning activity in this section of the lagoon. In the case of sediments, the mean $\mathrm{Zn}$ concentrations from the Sakumo II lagoon varied from $16.3 \pm$ 2.6 to $48.7 \pm 0.93 \mathrm{mg} / \mathrm{kg}$, with the mid-section recording the highest $\mathrm{Zn}$ value (Fig. 5), suggestive of high domestic and industrial sewage discharge.

In sediment from the feeder streams the mean $\mathrm{Zn}$ concentrations varied from $10.4 \pm$ 4.10 to $155.2 \pm 13.9 \mathrm{mg} / \mathrm{kg}$, with feeder stream 2 recording the highest $Z n$ value (Fig. 5). The high $\mathrm{Zn}$ value recorded in sediment from feeder stream 2 might be due to the weathering of minerals and soils and domestic effluents, since feeder stream 2 receives domestic effluents from Ashaiman and its environs, which is densely populated. Results also showed that sediment from FDS1 had $\mathrm{Zn}$ values which were not significantly higher than those from the Sakumo II lagoon, whilst sediment from FDS2 had higher Zn levels (highly significant at $P<0.001)$ relative to those from the Sakumo II lagoon (Table 6). Possible sources of $\mathrm{Zn}$ in sediment from the feeder streams include industrial effluents, urban stormwater runoff and domestic effluents.

Mean Zn concentrations in sediment from the Muni lagoon varied from $4.33 \pm 0.18$ to $13.7 \pm 0.18 \mathrm{mg} / \mathrm{kg}$, with the mid-section recording the highest $\mathrm{Zn}$ value (Fig. 6). A probable reason for the high $\mathrm{Zn}$ value in sediment from the mid-section of the Muni lagoon may be increased weathering of minerals and soils. The study showed that levels of $\mathrm{Zn}$ detected in both water 
(differences not significant) (Table 5) and sediment (differences highly significant at $P$ $<0.001$ ) (Table 6) from the Sakumo II lagoon were relatively higher than those detected in the Muni lagoon. This suggests the intense anthropogenic influence due to industrialization and urbanization within the catchments of the Sakumo II lagoon as against the absence of industries and low population (rural setting) in the Muni lagoon catchments. Results from the study showed that sediments from both lagoons were within the recommended value $(95 \mathrm{mg} / \mathrm{kg})$ of unpolluted sediments (Salomons \& Foster, 1984), except those from feeder stream 2 (155.2 mg/kg).

Copper. Copper $(\mathrm{Cu})$ is intimately related to the aerobic degradation of organic matter (Das \& Notling, 1993) and has been shown to cause acute gastrointestinal discomfort and nausea at concentrations above $3 \mathrm{mg} / \mathrm{l}$ (WHO, 2004). In the waters of Sakumo II lagoon, mean $\mathrm{Cu}$ concentrations varied from $0.112 \pm 0.009$ to $0.158 \pm 0.012 \mathrm{mg} / \mathrm{l}$, with the mid-section recording the highest $\mathrm{Cu}$ level (Fig. 3). The high $\mathrm{Cu}$ levels in this section of the Sakumo II lagoon could be attributed to the presence of relatively high oxygen and organic matter, thereby, enhancing the process of aerobic degradation of organic matter which, invariably, is intimately related to the deposition of $\mathrm{Cu}$ (Das \& Notling, 1993). The waters of feeder streams 1 and 2 recorded mean $\mathrm{Cu}$ concentrations varying from $0.099 \pm 0.010$ to $0.268 \pm 0.006 \mathrm{mg} / \mathrm{l}$, with feeder stream 1 recording the highest $\mathrm{Cu}$ value (Fig. 3). This suggests that the waters of feeder stream 1 may be relatively more oxygenated and may contain more organic matter than feeder stream 2, thus, enhancing aerobic degradation of organic matter and, thereby, depositing $\mathrm{Cu}$ in the waters (Das \& Notling, 1993) of feeder stream 1.

In the case of the Muni lagoon, mean $\mathrm{Cu}$ concentrations in water varied from $<0.002$ to $0.013 \pm 0.001 \mathrm{mg} / \mathrm{l}$. The highest $\mathrm{Cu}$ concentration recorded in the waters of the Muni lagoon was recorded in the northern section (Fig. 4). Results showed that levels of $\mathrm{Cu}$ detected in water from feeder streams 1 and 2 (differences not significant) were relatively higher than those from the Sakumo II lagoon (Fig. 3), suggesting that the feeder streams may be relatively more oxygenated and may contain relatively more organic matter. The feeder streams are, therefore, potential sources of $\mathrm{Cu}$ contamination to the Sakumo II lagoon. $\mathrm{Cu}$ levels in water from the Sakumo II lagoon were relatively higher (differences not significant) (Table 5) than those detected in the Muni lagoon. This is an indication of intense industrial and domestic influence as a result of industrialization (the presence of manufacturing industries such as Printex, Coca Cola Bottling, Kasapreko Company Ltd, etc.) and urbanization (residential facilities) in the Sakumo II lagoon catchments resulting in production of high organic matter which could possibly enhance the process of aerobic degradation (in the presence of oxygen) of organic matter (Das \& Notling, 1993).

Lead. The United States Environmental Protection Agency has classified lead $(\mathrm{Pb})$ as being potentially hazardous and toxic to most forms of life (USEPA, 1986a). Pb has been found to be responsible for quite a number of ailments in humans, such as chronic neurological disorders especially in foetuses and children. A concentration of 
$\mathrm{Pb}>0.1 \mathrm{mg} / \mathrm{l}$ is detrimental to foetuses and children with possible development of neurological problems.

In the Sakumo II lagoon, mean $\mathrm{Pb}$ concentrations detected in water varied from $<0.005$ to $0.057 \pm 0.003 \mathrm{mg} / \mathrm{l}$, with the southern section recording the highest $\mathrm{Pb}$ value (Fig. 3). The waters of the feeder streams recorded mean $\mathrm{Pb}$ concentrations varying from $0.020 \pm 0.00$ to $0.037 \pm 0.00$ $\mathrm{mg} / \mathrm{l}$, with feeder stream 2 recording the highest $\mathrm{Pb}$ value (Fig. 3). A probable source of $\mathrm{Pb}$ could be due to its persistence in the environment and from used dry-cell batteries resulting from the refuse dump around the area. Results from this study showed that the Sakumo II lagoon waters (Fig. 3) had higher $\mathrm{Pb}$ levels relative to the feeder streams (differences in $\mathrm{Pb}$ levels between Sakumo II lagoon and FDS1 not significant, whilst those between Sakumo II lagoon and FDS2 were highly significant at $P<0.001$ ).

The study also showed that sediment from the feeder streams had relatively high (differences not significant between Sakumo II lagoon and FDS1, whilst that between Sakumo II lagoon and FDS2 was significant at $P<0.001$ ) (Table 6) $\mathrm{Pb}$ values than those from the Sakumo II lagoon. Since sediments provide a deeper insight into the long-term pollution state of a water body, the feeder streams could be described as potential sources of $\mathrm{Pb}$ pollution to the Sakumo II lagoon.

In the case of the Muni lagoon, the waters had mean $\mathrm{Pb}$ concentrations ranging from $<0.005$ to $0.033 \pm 0.001 \mathrm{mg} / \mathrm{l}$ with the northern section recording the highest $\mathrm{Pb}$ value (Fig. 4). High $\mathrm{Pb}$ values in the northern section of the Muni lagoon may be due to atmospheric deposition resulting from its persistence in the environment. Results from the study showed that the waters of both Sakumo II and Muni lagoons may not be detrimental to foetuses and children with possible development of neurological problems since $\mathrm{Pb}$ levels in these waters were $<0.1 \mathrm{mg} / 1$. In the case of sediments, the Sakumo II lagoon had mean concentrations of $\mathrm{Pb}$ varying from $3.79 \pm 0.7$ to $29.2 \pm 3.2 \mathrm{mg} / \mathrm{kg}$, with the southern section recording the highest $\mathrm{Pb}$ value (Fig. 5). The feeder stream waters had mean $\mathrm{Pb}$ concentrations varying from $10.6 \pm 1.84$ to $37.4 \pm 3.07 \mathrm{mg} / \mathrm{kg}$, with feeder stream 2 recording the highest $\mathrm{Pb}$ value (Fig. 5). This confirms earlier suggestion that $\mathrm{Pb}$ persistence in the environment might be responsible for the high $\mathrm{Pb}$ levels in the waters of feeder stream 2 since $\mathrm{Pb}$ levels in sediment from feeder stream 2 (Fig. 5) was four times that in sediment from feeder stream 1 as against the two times that in their waters (Fig. 3). The high $\mathrm{Pb}$ levels in sediment from the feeder streams could be the result of flocculation of the waters in these streams resulting in the sedimentation of particulate $\mathrm{Pb}$.

For sediment from the Muni lagoon, mean concentrations of $\mathrm{Pb}$ varied from $0.556 \pm$ 0.02 to $1.46 \pm 0.18 \mathrm{mg} / \mathrm{kg}$, with the midsection recording the highest $\mathrm{Pb}$ value (Fig. 6). The high levels of $\mathrm{Pb}$ in the mid-section of the Muni lagoon relative to the northern and southern sections could be due to sewage effluent and runoff of waste since this portion of the lagoon is close to human settlements. Results from the study have shown that the levels of $\mathrm{Pb}$ detected in water and sediment from the Sakumo II lagoon were relatively higher (differences not significant) than those from the Muni lagoon, 
suggestive of possible impact of discharge of industrial and sewage effluents and domestic wastewater into the Sakumo II lagoon.

Results also showed that $\mathrm{Pb}$ levels detected in water (differences in values between Sakumo II and FDS 1 not significant, whilst those between Sakumo II and FDS2 were highly significant at $P<$ 0.001 ) and sediment (differences in values between Sakumo II and FDS 1 not significant, whilst those between Sakumo II and FDS2 were significant at $P<0.001$ ) from the feeder streams relative to those from the Sakumo II lagoon were higher (Fig. 3 and 5). This suggests that the feeder streams could be serving as potential sources of $\mathrm{Pb}$ contamination to the Sakumo II lagoon. The study also showed that sediment from the mid-section of Sakumo II lagoon $(29.2 \mathrm{mg} /$ $\mathrm{kg})$ and the feeder stream $2(37.2 \mathrm{mg} / \mathrm{kg})$ (Fig. 5) were outside the recommended values $(19.00 \mathrm{mg} / \mathrm{kg}$ ) of unpolluted sediments (Salomons \& Froster, 1984).

Manganese. $\mathrm{Mn}$ is an element of low toxicity having considerable biological significance and one of the more biogeochemical and active transition metals in aquatic environment (Evans et al., 1977). Mn occurs in surface waters that are low in oxygen and often does so with $\mathrm{Fe}$. Mn accumulates in certain species of fish (Uthe $\&$ Blish, 1971). The health based guideline value is $0.4 \mathrm{mg} / \mathrm{l}$ (WHO, 2004).

Mean Mn concentrations in water from the Sakumo II lagoon varied from $0.240 \pm$ 0.016 to $0.798 \pm 0.073 \mathrm{mg} / \mathrm{l}$, with the midsection recording the highest $\mathrm{Mn}$ value (Fig. 3 ). In the waters of the feeder streams, mean Mn concentrations varied from $0.777 \pm 0.05$ to $0.942 \pm 0.069 \mathrm{mg} / \mathrm{l}$, with feeder stream 1 recording the highest Mn value (Fig. 3). A probable source of airborne inorganic manganese pollutant in urban centres is the combustion of methylcyclopentadienyl manganese tricarbonyl (MMT), particularly in areas of high traffic density (Sierra et al., 1998). MMT is neutral in charge and contains organic groups, which makes it highly lipophilic and soluble in petrol. During vehicle combustion, weak bonds between the central metals and the organic groups readily break down in hot car engine environment. Combustion of MMT leads to the emission of manganese phosphates, manganese sulfate and manganese oxides that include manganese tetroxide as a minor component (Zayed, 2001; WHO, 2004). The high Mn levels in the mid-section of Sakumo II lagoon and feeder stream 1 could, therefore, be due to MMT, an anti-knocking agent present in petroleum products which has $\mathrm{Mn}$ as an active component.

Mean Mn concentrations in water from the Muni lagoon varied from $0.015 \pm 0.004$ to $0.434 \pm 0.02 \mathrm{mg} / \mathrm{l}$, with the northern section recording the highest $\mathrm{Mn}$ value (Fig. 4). Mean Mn concentrations in sediment from the Sakumo II lagoon varied from 153.1 \pm 19.4 to $668.2 \pm 6.3 \mathrm{mg} / \mathrm{kg}$, with the midsection recording the highest $\mathrm{Mn}$ value (Fig. $5)$. In the case of sediment from the feeder streams, mean Mn concentrations varied from $63.7 \pm 4.5$ to $298.21 \pm 2.5 \mathrm{mg} / \mathrm{kg}$, with feeder stream 2 recording the highest $\mathrm{Mn}$ value (Fig. 5). This suggests that there could be flocculation of the waters in Sakumo II lagoon and FDS2 resulting in the sedimentation of particulate $\mathrm{Mn}$, since $\mathrm{Mn}$ levels in sediment from feeder stream 2 was five times that from feeder stream 1 (Table 2 ), whilst, in contrast, Mn levels in the waters of feeder stream $1(0.94 \mathrm{mg} / \mathrm{l})$ was only slightly higher than feeder stream $2(0.78$ 
mg/l) (Table 1). Sediment from the Muni lagoon had mean Mn concentrations varying from $33.5 \pm 0.74$ to $63.8 \pm 1.50 \mathrm{mg} / \mathrm{kg}$., with the mid-section recording the highest $\mathrm{Mn}$ value (Fig. 6). This might be due to flocculation resulting in sedimentation of $\mathrm{Mn}$ in this section of the Muni lagoon.

Results showed that the levels of Mn detected in water from the feeder streams relative to those from Sakumo II lagoon were higher (differences in values between Sakumo II and FDS1 was significant at $P<$ 0.001, whilst those between Sakumo II and FDS2 were not significant) (Table 5), suggesting that the feeder streams could serve as sources of Mn contamination to the Sakumo II lagoon. However, sediment from the Sakumo II lagoon had higher Mn levels relative to those from the feeder stream (differences in values between Sakumo II and FDS 1 was highly significant at $P<0.05$, whilst those between Sakumo II and FDS2 were not significant) (Table 6). This confirms the ability of sediment to serve as a ready sink or reservoir for pollutants including trace metals (Onyari et al., 2003). The Muni lagoon had relatively lower Mn values for both water (differences in values significant at $P<0.01$ ) (Table 5) and sediment (differences in values significant at $P<0.01$ ) (Table 6). This could be attributed to the relatively less impact of human activity in the catchments of the Muni lagoon. Results (Tables 2 and 4) showed that $\mathrm{Mn}$ levels in sediments from both lagoons were within the recommended values $(777.0 \mathrm{mg} / \mathrm{kg})$ of unpolluted sediments (Salomons \& Froster, 1984).

Iron. Iron $(\mathrm{Fe})$ has frequently been used as an indication of natural changes in the trace metal carrying capacity of sediments (Rule, 1986), and its concentration has been related to the abundance of metal reactive compounds supposedly not significantly affected by man's action (Luoma, 1990). Fe is found in natural fresh- and groundwater, but have no health-based guideline value, although high concentrations give rise to consumer complaints due to its ability to discolour aerobic waters at concentrations above $0.3 \mathrm{mg} / \mathrm{l}$ (WHO, 2004). The mean Fe concentrations in water from the Sakumo II lagoon varied from $0.888 \pm 0.22$ to $1.82 \pm$ $0.63 \mathrm{mg} / \mathrm{l}$, with the northern section recording highest Fe value (Fig. 3). In the waters of the feeder streams, mean Fe concentrations varied from $0.715 \pm 0.03$ to $1.65 \pm 0.20 \mathrm{mg}$ / 1 , with feeding stream 2 recording the highest Fe value (Fig. 3). This may be due to natural occurrence, since the feeder streams are freshwaters which are produced from aquifers within which geochemical and biochemical processes take place, thereby, releasing $\mathrm{Fe}$ (WHO, 2004). The waters of the Muni lagoon recorded mean $\mathrm{Fe}$ concentrations varying from $0.307 \pm 0.021$ to $1.085 \pm 0.260 \mathrm{mg} / \mathrm{l}$ (Table 3), with the northern section recording the highest $\mathrm{Fe}$ value (Fig. 4). Results (Tables 1 and 3) showed that $\mathrm{Fe}$ values in water from the Sakumo II and the Muni lagoons, as well as the feeder streams, were all above the maximum limits $(0.3 \mathrm{mg} / \mathrm{l})$ beyond which there could be the discolouration of aerobic waters (WHO, 2004).

In the case of sediment, mean $\mathrm{Fe}$ concentration detected from the Sakumo II lagoon varied from $2563.2 \pm 22.3$ to 3074.6 $\pm 14.7 \mathrm{mg} / \mathrm{kg}$ (Table 2), with the northern section recording the highest $\mathrm{Fe}$ value. Probable sources of $\mathrm{Fe}$ in sediment from the northern section of the Sakumo II lagoon could be natural, as a result of natural geochemical and biochemical processes 
with the aquifers. In the feeder streams, mean $\mathrm{Fe}$ concentrations in sediment varied from $3208.6 \pm 50.5$ to $7486.9 \pm 23.5 \mathrm{mg} / \mathrm{kg}$ (Table 2), with feeder stream 2 recording the highest $\mathrm{Fe}$ value. The high $\mathrm{Fe}$ level in feeder stream 2 could be related to the abundance of metal reactive compounds supposedly not significantly affected by man's action (Luoma, 1990). In the case of sediment, mean Fe concentrations in the Muni lagoon varied from $2344.8 \pm 2.81$ to $3198.4 \pm 3.51 \mathrm{mg} / \mathrm{kg}$, with the mid-section recording the highest Fe value (Table 4).

The levels of $\mathrm{Fe}$ in water (differences in values not significant) from the Sakumo II lagoon were higher than those from the Muni lagoon (Table 5). This may be due to natural sources as a result of the geochemical and biochemical processes in the aquifers within the catchments. However, Fe levels in sediment from the Muni lagoon were relatively higher (differences in values not significant) (Table 6) than those from the Sakumo II lagoon. This could be attributed to natural occurrence. Fe levels in sediment from the feeder streams were relatively higher (differences in values not significant) (Table 6) than those from the Sakumo II lagoon (Fig. 5), suggesting that the feeder streams could be considered as potential sources of Fe contamination to the Sakumo II lagoon. Results (Tables 2 and 4) showed that Fe levels in sediments from both lagoons were within the recommended values $(41000.00 \mathrm{mg} / \mathrm{kg})$ of unpolluted sediments (GESAMP, 1982; Salomons \& Froster, 1984).

\section{Conclusion}

The study showed that the mid-section of the Sakumo II lagoon had higher trace metal levels than the southern and northern sections, indicative of the influence of intense anthropogenic activities in this section of the Sakumo II lagoon. The Mamahuma and the Gbagbla Ankonu streams, which feed the Sakumo II lagoon, serve as potential sources of trace metal pollution to the lagoon. Trace metal levels in sediment from the mid-section of the Muni lagoon were relatively higher than the southern and northern sections. However, the northern section of the Muni lagoon had higher trace metal levels in water. This suggests the relatively intense anthropogenic impact due to the salt winning activity in the northern section of the Muni lagoon. The levels of trace metals detected in sediment from the lagoons and the feeder streams were higher than those in water, thus, sediment could be described as a ready sink or reservoir of trace metals contamination in both the lagoons and the feeder streams. The study also showed that trace metal levels detected in both water and sediment from the Sakumo II lagoon were relatively higher than those from the Muni lagoon. Thus, the Sakumo II lagoon could be described as relatively more polluted with trace metal loads.

\section{Acknowledgement}

Financial support for the study was provided by the Government of Ghana. Facilities provided by the Environmental Chemistry Division, CSIR-Water Research Institute are hereby acknowledged. The authors gratefully acknowledge the immense assistance of Mr Michael Dorleku, Principal Technical officer, CSIR-Water Research Institute, for his participation in the sampling and analysis of the water samples. They also acknowledge the assistance of Mr John Rex Sappah and Mr Harrison Komladjei, Chief 
and Principal Draughtsmen, respectively, CSIR-Water Research Institute, for drawing the maps of the study areas.

\section{References}

Alabaster J. S and Lloyd R. (1980). Water Quality Criteria for Fish, 2nd edn. Butterworths, London.

Asami T. (1974). Environmental pollution by cadmium and zinc discharged from a braun tube factory. Ibaraki Daigaku Nogakubu Gakujutsu Hokakn. 22: 19-23.

Barcelona M., Gibb J. P., Helfrich J. A and Garske E. E. (1985). Practical guide for groundwater sampling. Ilinois State Water Survey ISWS Contract Report 37.

Birdlife International (2003). Birdlife's Online World Bird Database: The site for bird conservation. Version 2.0. Birdlife International, Cambridge, U.K.

Biney C. A. (1986). Preliminary physico-chemical studies of lagoons along the Gulf of Guinea in Ghana. Trop. Ecol. 27: 147-156.

Biney C.A. (1990). A review of some characteristics of freshwater and coastal ecosystems in Ghana. Hydrobiologia 208: 45-53.

Biney C. A. (1995). Environmental Baseline Studies-Limnology, Sakumo II Lagoon. Ghana Coastal Wetlands Management Project.

Biney C. A., Asmah R. and Asante K. A. (1998). Monitoring Pollution in Coastal Lagoons of Ghana. Gulf of Guinea Large Marine Ecosystem Project.

Borgmann U. (1983). Metal speciation and toxicity of free metal ions to aquatic biota. In Aquatic toxicity, Advances in Environmental Science and Technology. (J. O. Nriagu, ed.), Vol. 13, pp. 4773. John Willey \& Sons, New York.

Canadian National Laboratory for Environmental Testing (1994). Manual of Analytical Methods, Vol 2, Trace metals, pp. 02-2451-1 to 022451-14.

Claasen H. C. (1982). Guidelines and techniques for obtaining water samples that accurately represent the quality of an aquifer. U.S. Geological Survey Open File Report 82-1024. 49 pp.

Das J. D. and Nolting R. F. (1993). Distribution of trace metals from solis and sewage sludge's abay refluxing with aqua regia. Analyst 108: 277-285.
Department of Water Affairs and Forestry, (DWAF) (1996b). Water Quality Guidelines, Aquatic Ecosystem Use. Vol.1, 2nd edn. DWAF, Pretoria.

Evans D. W., Cutshall N. H., Cross F. H. and Wolfe D. A. (1977). Manganese cycling in the Newport estuary, North Carlifonia. Estuar. Coast. Mar. Sci. 5: 71-80.

GESAMP(IMO/FAO/IJNESCO/WMO/IAEA/UN/ IJNEP) (1982). The health of the oceans. Rep. Stad. GESAMP. 15: 108 and UNEP Res. Seas. Rep. Stud., 16: 108.

Goering P. L., Waalkes M. P. and Klaassen C. D. (1994). Toxicology of metals. In Zinc supplement overdose can have toxic effects. (R. Hess and B. Schmidt, ed.) J. Paediar, Haemetol. /Oncol. 24: 528-584.

Garcia E. M., Cabrera C., Sanchez J., Lorenzo M. L. and Lopez M. C. (1999).Chromium levels in potable water, fruit juices and soft drinks: influence on dietary intake. Sci. Tot. Envir. 241(13): 143-150.

Hall G. E., Pelchat J. C. and Vaive J. E. (2002). Sample collection, filtration and preservation protocols for the determination of 'total dissolved' mercury in waters. Analysis 127: 674-680.

Hess R. and Schmid B. (2002).Zinc supplement overdose can have toxic effects. J. Paediatr. Haematol./Oncol. 24: 582-584.

IAEA International Atomic Energy Agency (1989). Trace elements in marine sediments. Reference sheet SD-M-2/TM. Vienna, Austria.

Kwei E. A (1974). The coastal lagoons in Ghana and the ecology of the crab, Callinectes latimanus (Rathburt). (PhD Thesis). University of Ghana. $344 \mathrm{pp}$.

Luoma S. N. (1990). Processes affecting metal concentrations in estuarine and coastal marine sediments. In Heavy metal in the Marine Environment. (R.W. Furness and P. S. Rainbow, ed.), pp. 51-66. CRC Press, Boca Raton, FL, 1990.

Merian E. (ed.) (1991). Metals and their compounds in the environment. Occurrence, analysis and biological relevance. UCH, Wienheim-New YorkBasel-Cambridge.

Onyari M. J., Muohi A. W., Omondi G. and Mavuti K. M. (2003). Heavy metals in sediments from Makupa and Port-Reitz Creek systems: Kenyan Coast. Envir. Int. 28(7): 639-647. 
Prater B. E. (1975). The metal content and characteristics of Steel-work effluents discharging to the Tess estuary. Wat. Pollut. Cont. 74: 63-78.

Rule J. H. (1986). Assessment of trace metal element geochemistry of Hampton Roads and lower Chesapeake Bay area sediments. Envir. Geol. Wat. Sci. 8: 209-219.

Salomons W. and Froster V. (1984). Metals in the hydro cycle. Springer, Berlin. pp. 349.

Sierra P., Chakrabarti S., Tounkara R., Loranger S., Kennedy G. and Zayed J. (1998) Bioaccumulation of Manganese and its Toxicity in Feral Pigeons (Columba livia) Exposed to Manganese Oxide Dust $\left(\mathrm{Mn}_{3} \mathrm{O}_{4}\right)$. Envir. Res. 79(2): 94-101.

Uthe J. F. and Blish E. G. (1971). Preliminary survey of heavy metal contamination of Canadian fresh water fish. J. Fish. Res. Bd Can. 28: 786788.

UNEP (1984b) Determination of Total Cadmium,
Zinc, Lead, Copper in Selected Marine Organisms by Flameless Atomic Absorption Spectrophotometry, Reference Methods for Marine Pollution Studies No. 11, Rev.1.

United States Environmental Protection Agency (USEPA) (1986a). Quality Criteria for Water. United States Environmental Protection Agency office of Water Regulations and Standards. Washington DC, 20460.

Van Loon J. C. (1982). Chemical Analysis of Inorganic Constituent of Water. CRC Press.

Woodworth J. C. and Pascoe V. (1982). Cadmium toxicity to rainbow trout, Salmon gairdneri Richardson. A study of eggs and alevins. J. Fish. Biol. 21: 47-57.

WHO (2004). Guidelines for drinking-water quality, 3rd ed., World Health Organization, Geneva.

Zayed J. (2001). Use of MMT in Canadian Gasoline: Health and Environmental Issues. Am. J. Industr. Med. 39: 425-433. 